\title{
透過型防波堤を有する港湾での波浪変形計算と水理模型実験 \\ Computation of Wave Transfomation in Area with Permeable Breakwater and Hydraulic Model Test
}

高山知司 ${ }^{*}$ ・鈴木康正 ${ }^{* *}$. 平石哲也 ${ }^{* * *}$ - 森川高徳 ${ }^{* * * *}$

Tomotsuka Takayama, lasurasa Suzuki, Tetsuya Hiraishi and Takanori Morikawa

To prevent water pollution inside a port, a breakwater with piercing slits

is developed. The wave transmission of the breakwater should be considered

in the computation of wave transformation in the target port. The proposed

simulation model is verified by the model test.

Keywards: (Numerical simulation, Energy equivalance equation, Permeable breakwater)

\section{1.はじめに}

防波堤の第一義的な目的は, 高波の港内への侵入を遮断し港内を静穏に保つことである。そこで, 従来から遮 蔽効果が高く，耐波安定性に優れた直立ケーソン堤が防波堤として多用されてきた。しかしながら，荒天時には 有用なこれらの防波堤は, 静穏時にも海水の移動を妨げるので, 港内の水質の悪化の一因ともなっている。特に 近年は，港内においても’人にやさしい’親水性空間を創造する必要があり，静稳時に海水の流動を妨げず，環境 保全に有効な海水交換夕イプの透過型防波堤の開発が強く望まれる。

透過型の防波堤は，ケーソン堤の一部に港湾の内と外をつなぐ貫通部を設けたもので，外洋の波のエネルギー の一部が透過波となって港内へ侵入する。したがって, 透過型防波堤の遮蔽効果を推定し, 港湾計画を策定する ために重要な波浪変形計算においても，防波堤において透過する波のエネルギ一を計算できる機能を付加しなけ ればならない。従来, 捨石型防波堤の透過波を考慮した計算法は検討されている(椹木ら, 1992)が, 海水交換夕イ プを対象とし，平面模型実験で計算法の適用性を検討した例はない。本研究では，高山ら(1991)が提案した砕波， 反射を考慮したエネルギー平衡方程式による計算法を改良して，防波堤より透過してくる波のエネルギーを評価 できる数值計算法を確立し，そして，模型実験により数值計算法の検証を行うことを目的とした。

\section{2. 透過堤による波エネルギーの逸散}

沖波が防波堤などの構造物に到達するとき, 構造物両端部での回折や越波を除けば, 波は反射波となって, 進 行方向亡逆向きに進み，堤内への波の進入はない。

一方, 環境保全に有効な海水交換夕イプの透過型防波堤（以降, 透過堤と呼ぶ）は, 沖波が堤体に衝突した後 も, ある程度, 波が堤内へ進入する構造となっている。

このようなことから，透過堤が存在する場合の波浪変形計算を行なうためには，通常の無透過防波堤に対する 場合とは異なり，堤体の持つ透過率に応じて堤内への波エネルギーの進入を考慮しなければならない。

ここで, 高山ら(1991)の波浪変形計算手法で用いられた砕波の表現は, 水深の減少に伴い, 各成分波のエネル ギーをある割合で逐次減衰させることを基本とした。

したがって，透過堤を考慮する場合においても，波が堤体を通過して港内に進入する際，各成分波のエネルギ 一を，透過率に応じて減少させることを基本とした。

\section{3. 数値計算法}

(1) 波エネルギー低減効果の導入

高山ら(1991)の手法は，エネルギ一平衡方程式を拡張した式（1）を基礎式としている。

$\begin{array}{lllll}* & \text { 正会員 } & \text { 運輸省港湾技術研究所水工部長 } & \text { ( } 239 & \text { 横須賀市長瀬 3-1-1) } \\ * * & \text { 正会員 } & \text { 運輸省港湾技術研究所水工部波浪研究室長 } & & \\ * * * & \text { 正会員 } & \text { 運輸省港湾技術研究所水工部主任研究官 } & \\ \text { **** } & \text { 王野総合コンサルタント(株)海洋部 } & & \end{array}$


$\frac{\partial D_{\mathrm{s}} V_{\mathrm{x}}}{\partial x}+\frac{\partial D_{\mathrm{s}} V_{\mathrm{y}}}{\partial y}+\frac{\partial D_{\mathrm{s}} V_{\theta}}{\partial \theta}=-\varepsilon_{\mathrm{b}}^{\prime} D_{\mathrm{s}}$

ここに, $D_{\mathrm{s}}$ : 成分波のエネルギー

$V_{\mathrm{x}}: \mathrm{x}$ 方向の群速度成分

$V_{\mathrm{y}}: \mathrm{y}$ 方向の群速度成分

$V_{\theta}:$ 波向方向の群速度

$\varepsilon_{\mathrm{b}}^{\prime}$ : 単位時間当たりの砕波によるエネルギー逸散率

である。この式で，左辺は不規則波を構成する任意の成分波が, ある区間を進行し.た時のエネルギーフラックスの変化量で，第 1,2 項が浅水変形によるもの, 第 3 項が屈折によるものであ る。

ここで, 図 -1 に示す計算格子について考える。 $i, i$ はそれ ぞれ $\mathrm{x}$ および $\mathrm{y}$ 軸方向の格子番号, $\mathrm{n}$ は $\mathrm{N}$ 個に分割した周波数 の $\mathrm{n}$ 番目の周波数成分, $\mathrm{k}$ は $\mathrm{K}$ 個に分割した $\mathrm{k}$ 番目の波向であ る。

まず，図一1（a）についてエネルギーの流出入を考える際， 高山ら(1991)は砕波によるエネルギーの逸散を考慮しており，

これが, 式 (1) の- $\varepsilon_{\mathrm{b}}^{\prime} D_{\mathrm{s}}$ の形で表されている。

このような高山らの手法をさらに拡張して, 図一1(b)のよ うな透過堤配置をした計算格子を考えるとき，透過堤を通過す

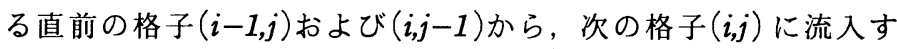
る波エネルギーを透過率 $K_{\mathrm{t}}$ に応じて減少させる。

具体的には, 格子 $(i-1, j) お よ ひ ゙ ~(i, j-1)$ から透過堤を通過し て格子 $(i, j)$ に流入するエネルギーを各々， $D I_{\mathrm{sn}}^{i-1, j, k}$, $D I_{\mathrm{s} n}^{i, j-1, k}$ とすると,

$$
\begin{aligned}
& D I_{\mathrm{s}}^{i-1, j, k}=K_{\mathrm{t}}^{2} D_{\mathrm{s}}^{i-1, j, k} \\
& D I_{\mathrm{s}}^{i, j-1, k}=K_{\mathrm{t}}^{2} D_{\mathrm{s}}^{i_{\mathrm{n}}, j-1, k}
\end{aligned}
$$

とみなして，数值計算を行う。

\section{（2）境界条件による透過堤の認識}

透過堤の存在および各種配置パターンは境界条件によって認識させる。また, 本計算では, 港内からの反射波 の透過堤再通過を考慮している。この場合, 格子条件が異 なってくるが, これはプログラム内で自動的に処理できる ようになっている。なお，透過堤の処理に関する部分以外 はすべて高山ら(1991)の方法にしたがっている。また，本 計算法の詳細は文献(鈴木ら, 1994)に示している。

\section{4. 本計算法の妥当性の検討}

本計算法の妥当性を検討するため, 第四港湾建設局が実 施した透過堤を対象しする港内静榣度模型実験(小笹ら, 19 92)の結果と本計算結果との比較を行った。

(1) 実験(小笹ら, 1992)の概要

a ) 実験装置

実験は第四港湾建設局下関調査設計事務所所有の潮流 • 波浪実験場内潮流・波浪実験水槽で行われた。

図 -2 は実験水槽平面図で, 長さ $61 \mathrm{~m}$, 幅 $48.5 \mathrm{~m}$, 高さ

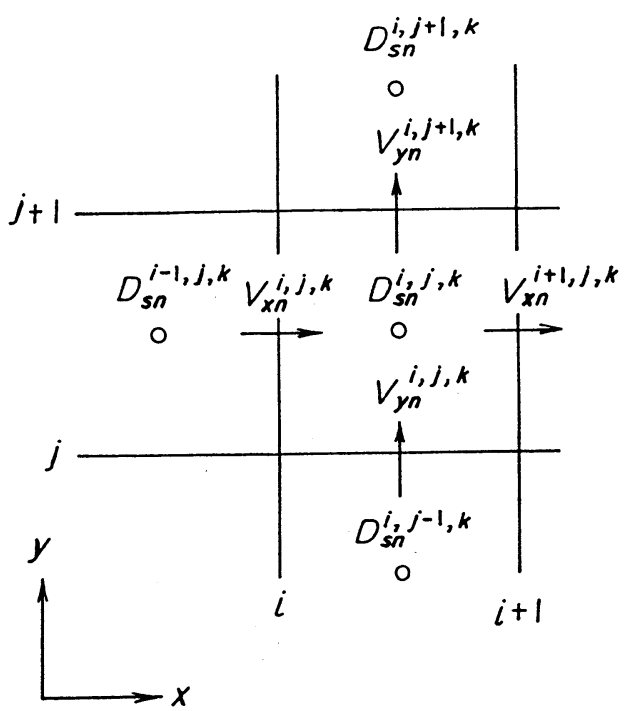

（a）透過堤がない場合

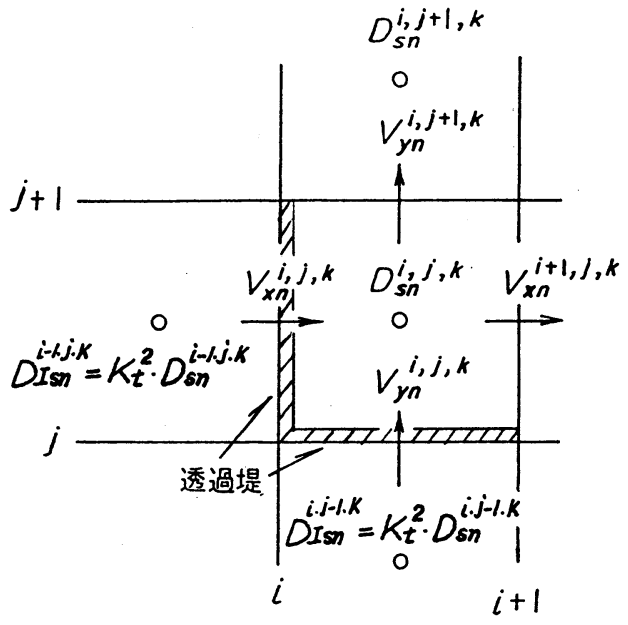

（b）透過堤がある場合

図-1 計算格子内における

成分波エネルギーの流出入

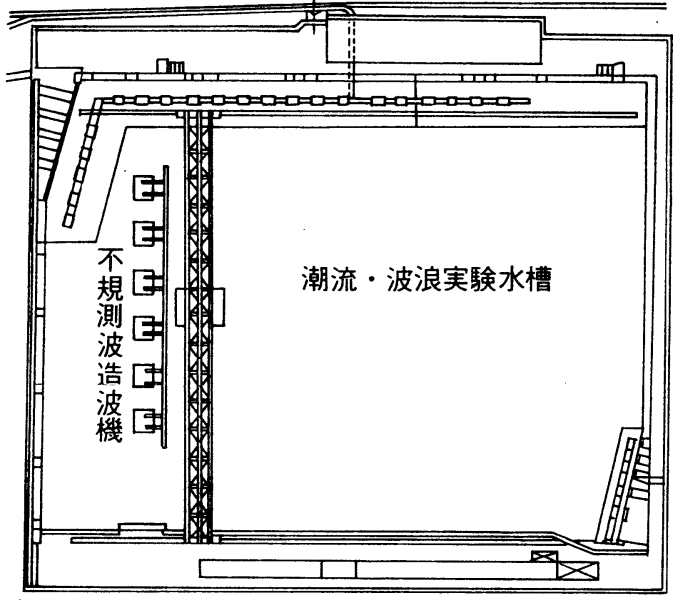

図 - 2 実験水槽平面図（小笹ら, 1992） 
$1.5 \mathrm{~m}$ を有し，水槽北側に単一方向不規則波造波装置（ピストン型）が 6 台設置してある。

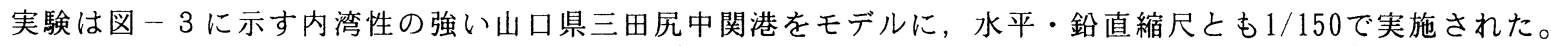

図-4は透過堤模型の構造であり，透水のために下部に開口部を有している。この防波堤は，水路による大縮 尺断面実験の結果, H. W. L $+3.33 \mathrm{~m}$, 有義波高 $3.9 \mathrm{~m}$, 有義周期 $9.2 \mathrm{~s}$ の条件で, 反射率 $67 \%$, 透過率 $42 \%$ の特性を 有すことが判明している。実験では, この透過堤模型を, 図一 3 のように港口部に 2 箇所設置し, 各々, 東防波 堤および西防波堤とした。

b ) 実験および解析方法

実験で目標とした不規則波の諸元および潮位条件は断 面実験に合わせ, 有義波高 $3.9 \mathrm{~m}$, 有義周期 $9.2 \mathrm{~s}$, H. W. L+3. $33 \mathrm{~m}$ とした。主な実験ケースとしては 2 本の防波堤 のうち, 東防波堤の延長は $470 \mathrm{~m}$ で一定とし, 西防波堤の 延長を $300 \mathrm{~m}, 600 \mathrm{~m}$ の 2 ケースに変化させた。

主要な波高形設置位置は図-3に示す防波堤背後の a 付近に 5 点, $\mathrm{b}$ 付近に 5 点, 人工島周辺の $\mathrm{c}$ 付近に 6 点, $\mathrm{d}$ 付近に 8 点, $\mathrm{e}$ 付近に 5 点, $\mathrm{f}$ 付近に 4 点, 港奥部の $\mathrm{g}$ 付近に 4 点, $\mathrm{h}$ 付近に 6 点, $\mathrm{i}$ 付近に 5 点, $\mathrm{j}$ 付近に 7 点, $\mathrm{k}$ 付近に 6 点, 計 61 点としている。

波浪データの取得は造波開始後10分間程待って, 波の 場が定常状態に達してから行った。取得したデータはオ ンラインで水理模型実験デー夕処理装置に入力し, A D 変換器によってデジタル化されている。なお, A D 変換

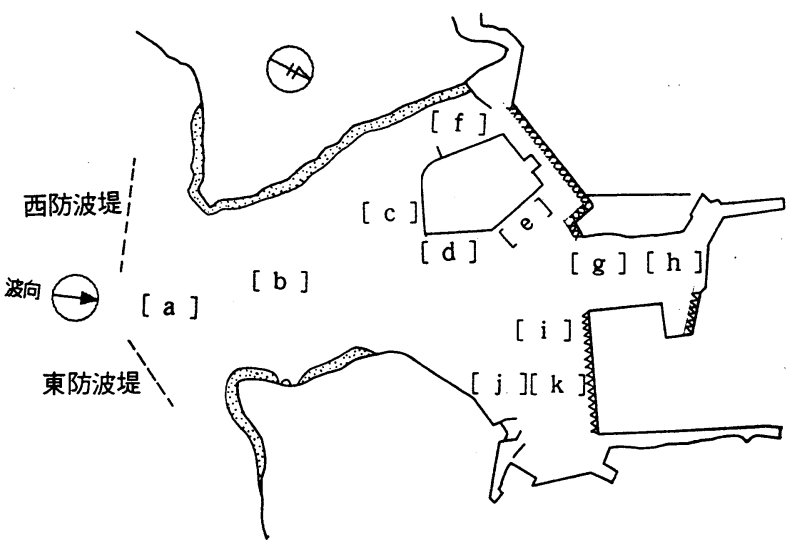
時のサンプリング時間間隔は $0.04 \mathrm{~s}$ である。そして，変

図-3 三田尻中関港の波高計設置領域

換したデー夕を処理装置内で統計解析し，各測点の周波数スペクトル，有義波高，有義周期等が求められている。

測定結果の表示方法としては，上述の $\mathrm{a} \sim \mathrm{k}$ までを各区域とみなし，各区域に属する測定点での波高を平均し， その值をその区域の代表波高としている。

\section{（2）計算条件}

計算に際しては，実験(小笹ら, 1992) に準じて，入射波の諸元を波高 $3.9 \mathrm{~m}$, 周期 $9.2 \mathrm{~s}$, 方向集中度パラメー夕は単 一方向不規則波を考慮して S max $=100$ 0 とし, 計算メッシュは, 図一 5 に示す 領域 1 (沖領域) $150 \mathrm{~m}$, 領域 2 (岸 領域）を $75 \mathrm{~m}$ とした。また，計算ケー スとして, 西防波堤 $300 \mathrm{~m}$ 時と $600 \mathrm{~m}$ 時 の 2 ケースを対象に，いずれも透過率

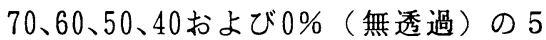
ケースで計算し, 総計10ケースについ て行った。

結果については，先の $\mathrm{a} \sim \mathrm{k}$ 区域毎 に, 図一 5 のとおり波高計設置点に相 当する位置の計算格子点を選定し, 各
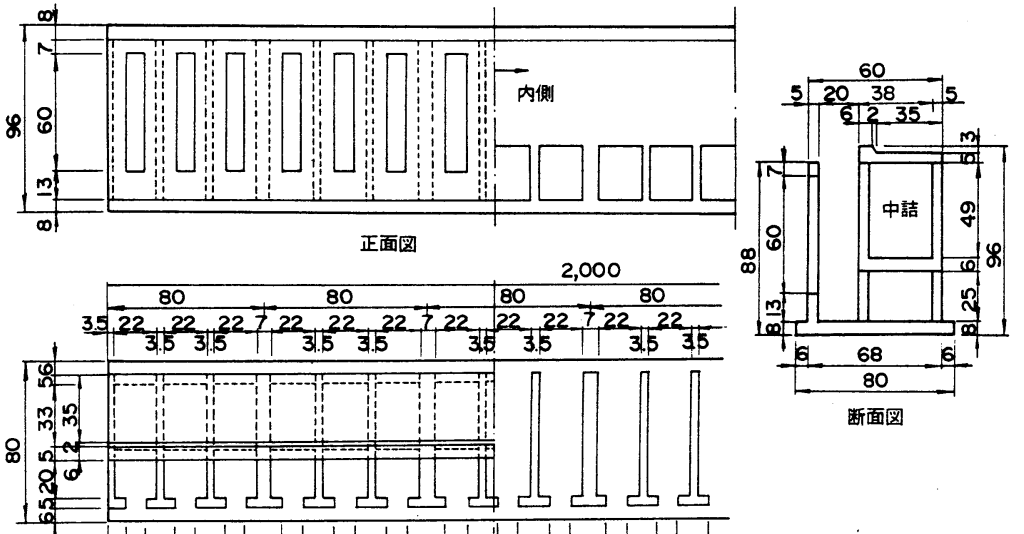
区域に属する計算格子点での有義波高

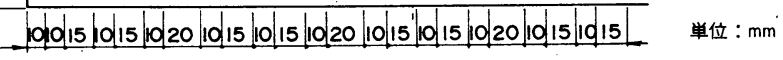
平面図

図-4 透過堤の構造(小笹ら, 1992)

値の平均を当該区域の代表波高值とした。なお，有義波高は，入・反射合成波高として算出した。

（3）計算値と実験値(小笹ら, 1992)との比較

a ) 西防波堤の延長が $300 \mathrm{~m}$ の場合

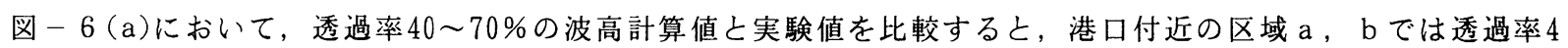
$0 \%$ の計算結果が実験值と $2 \sim 6 \%$ 差でよく一致している。

区域 c, d, e, f では, 計算值が実験值よりもやや低い傾向にあるが, 区域 $\mathrm{e}$ を除き両者の差は小さく, 透 過率 $50 \%$ の計算值と比較して，12 17\% 程度である。港奥部の区域 $\mathrm{g}, \mathrm{h}$ をると, 区域 $\mathrm{g}$ では透過率 $40 \%$ 值が 
実験値と一致し，区域 $\mathrm{h} も ，$ 透過率 $50 \%$ 値が実験値と 10 \%程度の差でほぼ一致している。

一方，区域 i，j，kでは，いずれの計算値も，実験 值を上回る結果となっており, その差は, 透過率 $40 \%$ 値 と比べて，32〜 62\%程度ある。

b）西防波堤の延長が600mの場合

図一6(b)について, 全体傾向をみると, 防波堤の延長 が長くなったことから，波高は計算值，実験値とも西防 波堤 $300 \mathrm{~m}$ 時に比較して減少している。次いで, 区域別に みると, 港口付近の区域 a , b では, 透過率 $40 \%$ 值が実 験值と $2 \%$ 以内の差でよく一致している。区域 $c, d$, $\mathrm{e}, \mathrm{f}$ では, 前項之同様, 計算值が実験值より低い傾向 にあるが，区域 $\mathrm{f}$ を除いてその差は小さく，透過率50\% 值と比較して，9～22\%程度である。港奥部の区域 $\mathrm{g}, \mathrm{h}$ では，透過率40\%值が実験値と一致している。

一方，区域 i ，j，kでは，前項と同様，いずれの計 算値も，実験值を上回る結果となっており，その差は透 過率 $40 \%$ 値と比較して，18～43\% 程度ある。

c）計算値と実験值の整合性

前項までの結果について，各区域の位置的特性等を考 慮しつつ検討を加える。

はじめに, 本地形における波浪変形の傾向についてみ ると，港口部付近では，実験時の観察でもみられている ように，防波堤による回折の影響は小さい。これは，本 防波堤が透過型であること，および，入射波長が防波堤 や開口部に対し短いことなどによる。

また，港内に向けては，水深が浅く変化していること から, 港内の波浪変形は浅水変形や屈折, 反射が支配的 になるものと思われる。

次いで, 区域別に検討すると, 港口部の区域 $a, b$, 透過堤の背後に位置するとともに，港内構造物からの多 重反射の影響が少ないことから，防波堤の透過効果を直 接的に受ける区域である。当該区域の比較結果では，西 防波堤 $300 \mathrm{~m}$ 時, $600 \mathrm{~m}$ 時のいずれのケースにおいても，

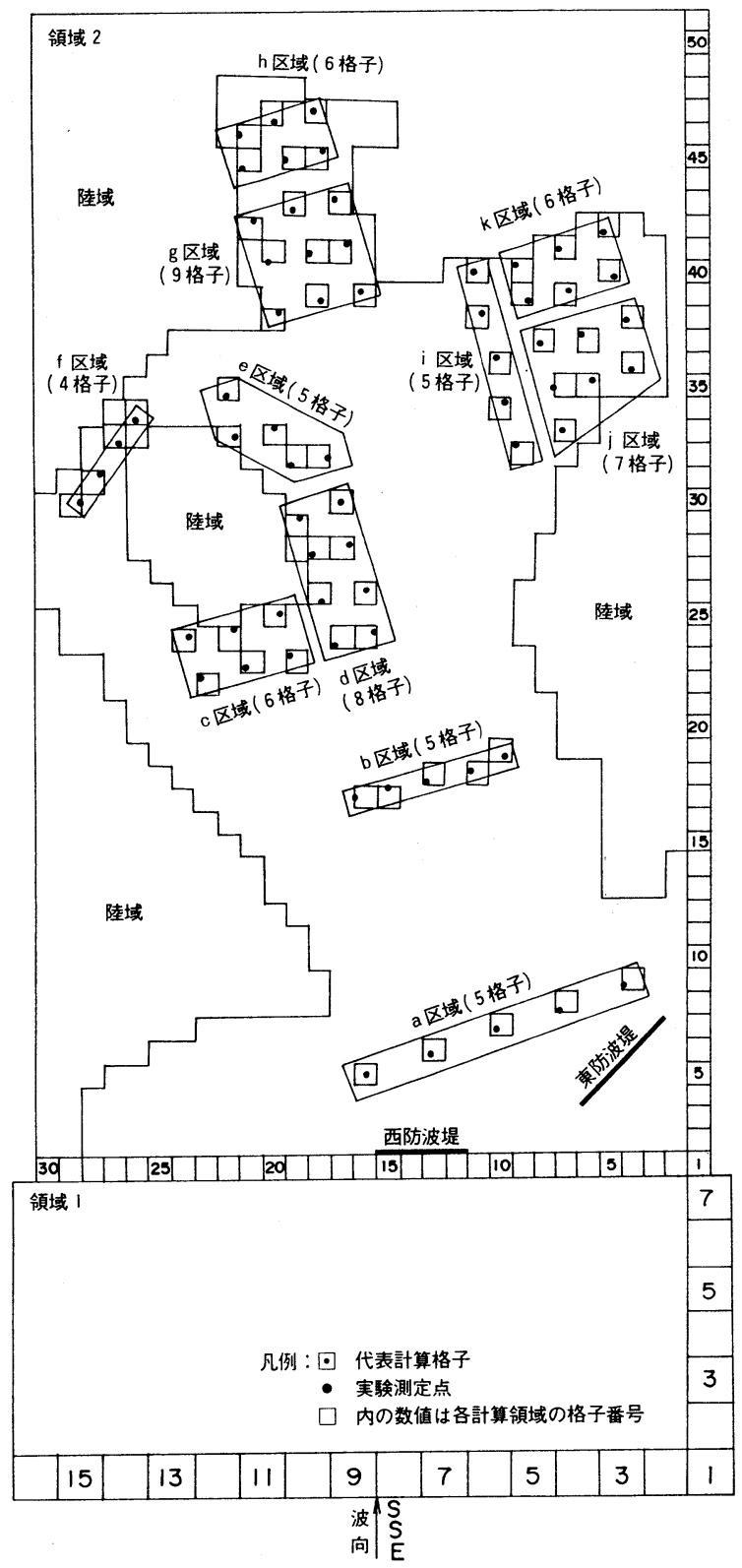

図-5 計算領域および代表計算格子
$\mathrm{H} 13$

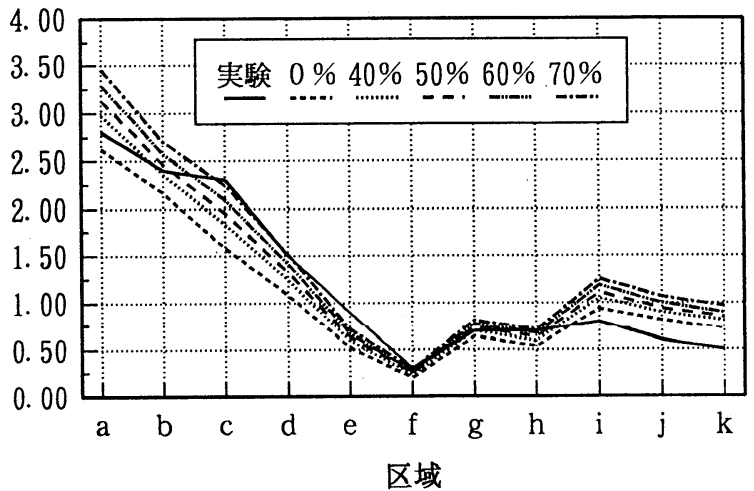

(a) 西防波堤 $300 \mathrm{~m}$
$\mathrm{H} 13$

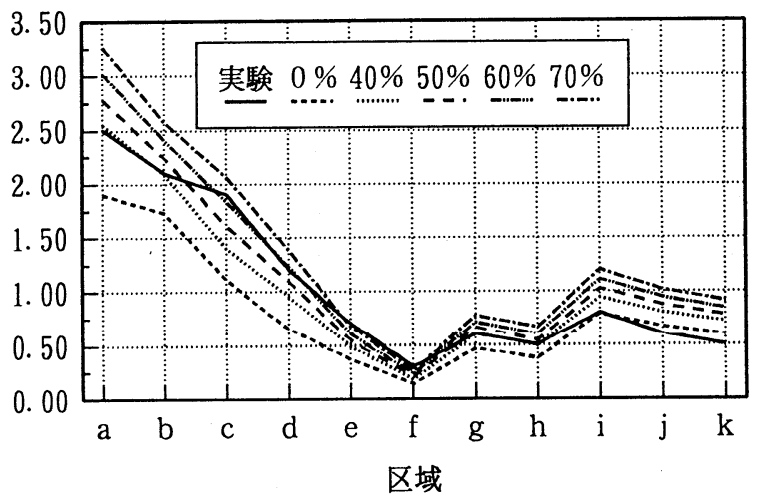

(b) 西防波堤 $600 \mathrm{~m}$ 
透過率 $40 \%$ の計算值が実験值と $6 \%$ 以内の差でよく一致していた。

区域 c , d , e では, 両ケースとも, 透過率40～50\%の計算值が実験值よりやや低い傾向にあった。このうち， 区域 $\mathrm{c}, \mathrm{d}$ は人工島前面に位置し, 実験時に護岸の反射を直接受けやすく, 特に, 区域 $\mathrm{d}$ では対岸からの一, 二 次反射もある。

また，区域 e は，人工島背後に位置し，実験時に人工島以奥からの反射波が多重になりやすい。ここで，本計 算法は反射波を考慮しているが，反射境界は格子形状（直角形状）で表現せざるを得ず，実験時の反射を正確に 再現することは困難であり，上述のように多重反射が生じてくると，誤差も一層蓄積される。ここに，実験値と 計算值の差が生じたものと思われる。ただし，前述のとおり，区域 e を除き，実験值と透過率 $50 \%$ 値の差は $15 \%$ 以下と少ない。

人工島背後に位置する区域 $\mathrm{f}$ も，計算值が実験值を下回る結果となったが，本区域も反射の影響が強く，これ が誤差となって表れたものと推察する。ただ，波高自体が0. $3 \mathrm{~m}$ 以下と小さく，両者の差は問題にならないものと 思われる。港奥部に位置する区域 $\mathrm{g}$ および $\mathrm{h}$ をると, 区域 $\mathrm{g}$ では両ケースとも透過率 $40 \%$ 值が実験值と一致し ている。

一方，区域 h では，西防波堤 $300 \mathrm{~m}$ のケースで，透過率40～50\%值が実験值より低い值となったが，これは，当 該区域が港の最奥に位置し，実験時に3 壁面からの複雑な反射が生じたことによる誤差であるものと推察される。 ただ，この場合も，透過率 $50 \%$ 值と実験値との差は $10 \%$ とさい。

区域 i，j，kでは，いずれのケースも，計算值が高い值を示し，透過率0\%（不透過）の条件でも，ほとんど の区域で，計算值が実験値を上回る結果となってい る。ここで，実験時での各区域に属する測定点の波 高を確認したところ，いずれの区域も護岸前面付近 の測定点で波高が急減しており,これが実験での平 均波高を下げている。波高が急減した要因として， 当該区域には図 - 3 のように，河川や各種凹凸が存 在することが挙げられ。本計算ではこれらの地形条 件を考慮しておらず，またここらの地形条件に対 し，計算時に設定した護岸反射率が妥当でなかった ことが，本計算值と実験值の差となって表れた可能 性がある。なお，護岸前面付近の測点を除けば，実 験值と透過率 $40 \%$ 值との差は最大でも $35 \%$ 程度とな ってくる。

以上のように，42\%の透過率を有す透過堤を用い た実験値と計算值を比較すると，西防波堤の延長 30 $0 \mathrm{~m}, 600 \mathrm{~m}$ のケースとも, 透過堤の影響を直接受け る港口部の区域で，透過率 40\%の計算值が実験値と よく一致した。その他の区域でも，多重反射の影響 を強く受ける区域や地形が複雑に変化する区域を除 き，透過率 $40 \sim 50 \%$ 值と実験值は $15 \%$ 以内の差でほ ぼ一致した。したがって，本計算手法は，透過堤が 存在する海域での波浪変形計算に適用可能であるも のと判断できる。

\section{（4）透過効果について}

図 $-7(\mathrm{a}) \sim(\mathrm{c})$ は, 本計算手法より求めた透過率 70\%，40\%および無透過の3ケースにおける港内波 高分布である。計算条件は，東防波堤 $470 \mathrm{~m}$ ，西防波 堤 $600 \mathrm{~m}$ ，波の諸元は前項と同じく，有義波高 $3.9 \mathrm{~m}$ ， 有義周期 $9.2 \mathrm{~s}, S \max =1000$ ，その他の条件（計算格 子等）も前項と同じである。

はじめに, 無透過のケースでは, 東・西防波堤背 後の波高は $1 \mathrm{~m}$ 以下亡なって打り，港内中央部から奥 部にかけても大部分が $1 \mathrm{~m}$ 以下の分布となっている。

透過率 $40 \%$ のケースでは，西防波堤背後の波高は 1
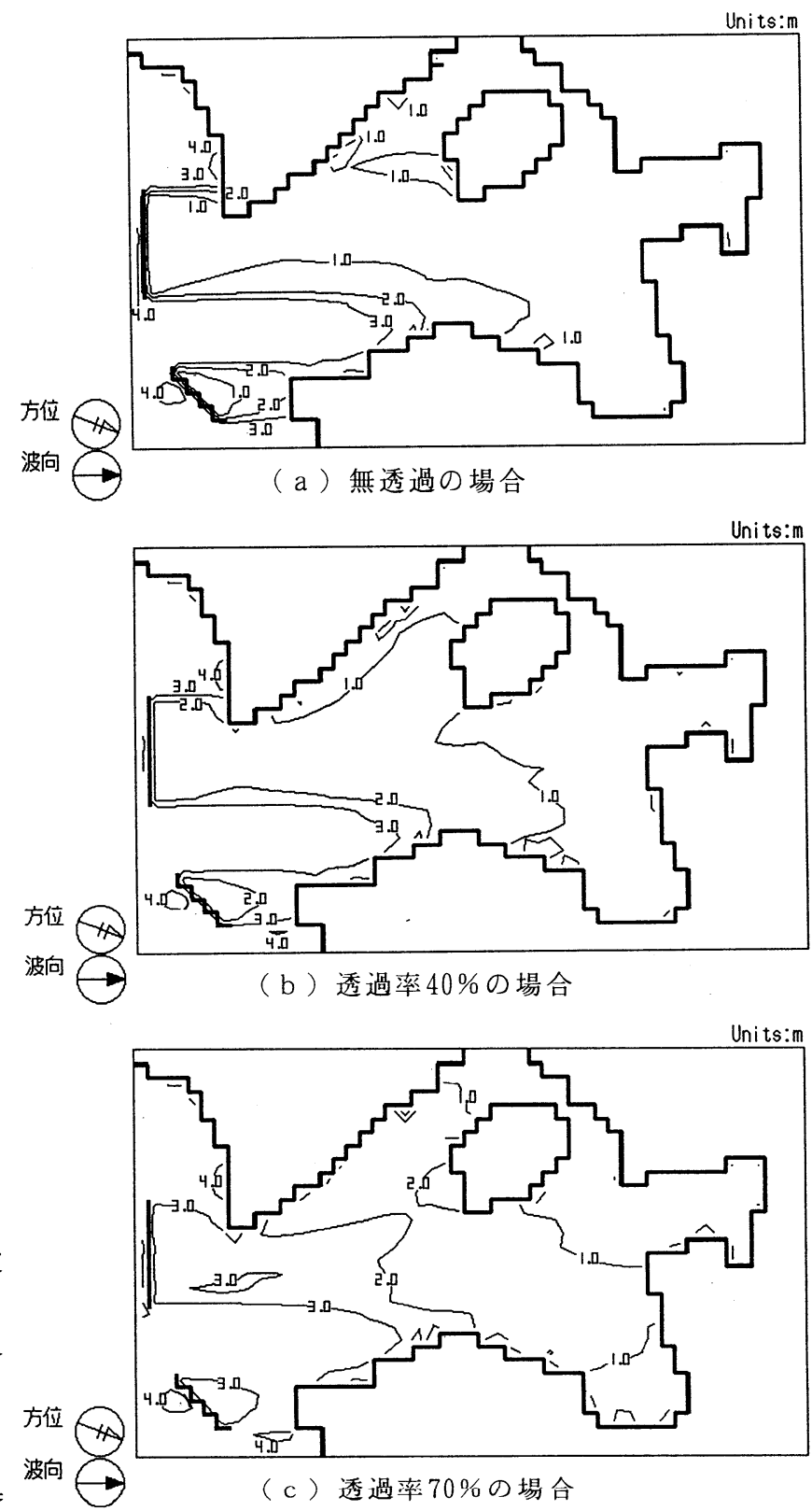

図 - 7 透過率の違いによる波高分布の比較 
$\mathrm{m}$ 以上となり，その分布は港内中央部に及んでいる。東防波堤背後の波高も西防波堤同様 $1 \mathrm{~m}$ 以上となっている。 透過率70\%のケースになると, 西防波堤背後の波高は $2 \mathrm{~m}$ 以上となり, その分布は港内中央部手前付近まで広が っている。さらに, 波高 $1 \mathrm{~m}$ 以上の範囲も, 港内中央部から一部港奥部にまで達している。また, 東防波堤背後の 波高も西防波堤同様 $2 \mathrm{~m}$ 以上となっている。

以上のように, 海水交換型防波堤の透過率が港内波高に及ぼす影響は大きく, 当該防波堤の計画, 設計に際し ては，港内の利用状況を十分考虑した上で目標透過率を設定する必要があることが分かる。

\section{5.まとめ}

本研究では, 高山ら(1991)が開発した砕波, 反射を考慮した波浪変形計算手法を改良して, 港内の水質環境保 全の観点から近年要請が高まっている海水交換タイプの防波堤が存在する港湾に適用できる波浪変形計算法の確 立を試みた。

そして，計算手法の妥当性を検討するため，第四港湾建設局が実施した透過率 $42 \%$ （断面実験時）の特性を有 す透過堤を用いた平面水理模型実験（小笹ら,1992)との比較を行った。計算に際しては，実験と同じく；港口部に 配置する東, 西 2 本の透過堤のうち, 東は延長 $470 \mathrm{~m}$ で一定とし, 西の延長を $300 \mathrm{~m}$ と $600 \mathrm{~m}$ の 2 ケースに変化させ

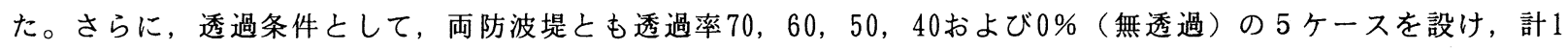
0ケースの計算を実施した。

その結果，以下のことを確認することができた。

1)西防波堤の延長に関わらず，透過堤の影響を直接受ける港口部の区域で, 透過率 $40 \%$ で実施した計算値が実 験值と6\%以内でよく一致した。

2)その他の区域についても，多重反射の影響が強い区域や地形が複雑に変化する区域を除き，透過率 40 ～50\% 値と実験值は $15 \%$ 以内の差でほぼ一致した。

以上のことから, 今回の計算手法は, 透過堤が存在する港湾での波浪変形計算に適用可能であるものと判断す る。

なお，本研究を遂行するに当たり，模型実験結果を提供して頂いた第四港湾建設局下関調查設計事務所の皆様， 資料解析用プログラムを提供頂いた港湾技術研究所波浪研究室河合弘泰研究官には深く感謝する次第である。

(参考文献)

小笹博昭・永末英之・佐野喜久雄 (1992) : 三田尻中関港静穏度実験報告書, 運輸省第四港湾建設局下関調査設計 事務所.

椹木 亨・井田康夫・後野正雄・菅 智浩 (1992)：透過性構造物による波変形の模型実験の限界について，第39 回海講論文集, pp616-620.

鈴木康正・森川高徳・平石哲也・望月徳雄 (1994)：浅海域における波浪変形計算法の拡張，港研資料No. 767, 35p 高山知司・池田直太・平石哲也 (1991)：砕波および反射を考慮した波浪変形計算, 港湾報告, 第 30 巻, 第 1 号, pp. 21-67. 